\title{
Photodegradation of Fenitrothion in Water and on Soil Surface, and Its Hydrolysis in Water
}

\author{
Nobuyoshi Mikami, Kumiko Imanishi, Hirohiko Yamada \\ and Junshi Miчamoto \\ Laboratory of Biochemistry and Toxicology, Takarazuka Research Center, \\ Sumitomo Chemical Co., Ltd., Takatsukasa, Takarazuka 665, Japan
}

(Received December 24, 1984)

\begin{abstract}
On exposure to sunlight, fenitrothion was photodecomposed with the half-lives of $0.6-$ 1.0 days in distilled water, $1.5,1.0$, and 0.9 days in buffer solutions at $\mathrm{pH} 3,7$ and 9 respectively, and 0.9-1.1 days in natural river and sea water. The quantum yield was determined to be $8.0 \times 10^{-4}$ (at $313 \mathrm{~nm}$ in distilled water), and the half-life of disappearance at 40 degree north latitude was calculated to be 1.4 days in fall. Fenitrothion applied on two kinds of soil thin layer plates promptly disappeared through photodegradation and volatilization, with the half-life of approximately 1 day. The insecticide underwent photo-induced oxidation of $\mathrm{P}=\mathrm{S}$ to $\mathrm{P}=\mathrm{O}$, oxidation of the aryl methyl group to the carboxyl group, reduction of the nitro group to the amino group, coupling of the carboxy group with the amino group leading to the formation of the dimeric compound, cleavage of the $P$-O-aryl or $P$-O-methyl linkage, isomerization, formation of the benzoisoxazole derivative with subsequent formation of the seven-membered ring (azepine derivative) through Beckmann rearrangement, and photomineralization of the aromatic ring to carbon dioxide in water, and oxidation of $\mathrm{P}=\mathrm{S}$ to $\mathrm{P}=\mathrm{O}$ and cleavage of the $P-O$-aryl linkage on soil. The formation of the major photoproducts in water was $\mathrm{pH}$ dependent. The carboxy derivative oxidized at the aryl methyl group of fenitrothion was predominant in distilled water at $\mathrm{pH} 5.9$ and in buffer solutions at $\mathrm{pH} 3$ and 7 , while the dimeric compound, composing of the carboxy derivative of fenitrothion and the corresponding amino analog, was more predominantly formed in buffer solutions at $\mathrm{pH} 7$ and 9, and natural river $(\mathrm{pH} 7.4)$ and sea $(\mathrm{pH} \mathrm{7.8)}$ water. On prolonged exposure to sunlight, these photoproducts were degraded further to ${ }^{14} \mathrm{CO}_{2}$ and the unextracted residues, which were considered to be the polymerized compounds like humic acid and other highly polar products. Fenitrothion underwent hydrolysis through neutral $(\mathrm{pH}$ independent) and basecatalyzed processes below $\mathrm{pH} 7$ and above $\mathrm{pH} 10$ respectively, while both reactions occurred between $\mathrm{pH} 7$ and $\mathrm{pH}$ 10. The half-lives of disappearance by hydrolysis within the ranges of $\mathrm{pH} 5-9$, normally found in natural water, were about $200-630$ days at $15^{\circ} \mathrm{C}, 17-61$ days at $30^{\circ} \mathrm{C}$, and $4-8$ days at $45^{\circ} \mathrm{C}$. The product cleaved at the $P-O$-aryl linkage was predominant above $\mathrm{pH} 10$, while the product cleaved at the $P$-O-methyl linkage was predominant below $\mathrm{pH}$ 8. The rates and pathways of degradation of fenitrothion by photolysis and hydrolysis in natural river and sea water were similar to those in buffer solutions at the same $\mathrm{pH}$.
\end{abstract}

\section{INTRODUCTION}

Fenitrothion [Sumithion ${ }^{\circledR}, O, O$-dimethyl $O$ (3-methyl-4-nitrophenyl)phosphorothioate] (I) is an organophosphorus insecticide which has been widely used for forest protection and for the control of various plant pests and house- hold insects. From the environmental safety view point, I has been extensively studied, particularly with respect to behavior and degradation in the field. The previous study on the degradation in various solvents and as films under both UV and sunlight has shown that I was rapidly degraded via photo-induced 
isomerization, oxidation, hydrolysis and solvolysis. $^{1,2)}$ A main reaction in distilled water was oxidation at the aryl methyl group leading to the formation of $O, O$-dimethyl $O$-(3-carboxy4-nitrophenyl) phosphorothioate (XII). ${ }^{1)} \quad$ Recently, it has been reported that the major photoproducts in sea water were dimeric compounds composing of XII and the amino derivatives, ${ }^{3)}$ and different from those in distilled water. Further, Greenhalgh et al. ${ }^{4)}$ clarified that the hydrolysis of $\mathbf{I}$ in water was $\mathrm{pH}$ dependent. Therefore, the experiments were extended in order to clarify the $\mathrm{pH}$ dependence on the rates and routes of conversion by photolysis and hydrolysis in water.

This paper deals with the photolysis of $\mathbf{I}$ in distilled water and buffer solutions at $\mathrm{pH} 3$, 7 and 9, along with the hydrolysis study in buffer solutions at $\mathrm{pH} 2-11.5$, and natural river and sea water. Photodegradation of $\mathbf{I}$ on soil surface was also examined.

\section{MATERIALS AND METHODS}

\section{Radiolabeled Compound}

Fenitrothion (I) labeled with ${ }^{14} \mathrm{C}$ in the phenyl ring was prepared by Yoshitake et al. ${ }^{5)}$ in Takarazuka Research Center of Sumitomo Chemical Co., Ltd. The ${ }^{14} \mathrm{C}$ preparation had a specific activity of $20.4 \mathrm{mCi} / \mathrm{mmol}$, with more than $99.8 \%$ radiochemical purity as determined by thin-layer chromatography (TLC).

\section{Unlabeled Compounds}

The compounds shown in Fig. 3 were obtained or synthesized as reference standards, and the $R f$ values by TLC were reported elsewhere. ${ }^{1-3)}$

\section{Radioassay}

Liquid scintillation counting (LSC), combustion analysis and autoradiography were carried out according to the methods reported previously. ${ }^{6)}$

\section{Thin-layer Chromatography (TLC)}

Extracts were applied as spots or bands on silica gel $60 \mathrm{~F}_{254}$ thin layer plates (E. Marck) and chromatographed in the following solvent systems: A) chloroform/methanol (3/1); B) toluene/ethyl formate/formic acid $(5 / 7 / 1) ; \mathrm{C})$ toluene/acetic acid (7/1). The solvent systems for two-dimensional development are illustrated for example as follows: $(\mathrm{A} \times \mathrm{B})$ indicates development in the first direction with solvent system A and in the second direction with solvent system $B$. The radioactive area on TLC plates were detected by autoradiography and unlabeled compounds were detected by UV light or by spraying $2 \% \mathrm{PdCl}_{2}$ solution in $2 \mathrm{~N} \mathrm{HCl}$ ( $\mathrm{P}=\mathrm{S}$ compounds).

\section{Photolysis of Fenitrothion in Water}

Distilled water, natural river and sea water, and buffer solutions ( $\mathrm{pH} \mathrm{3,7}$ and 9) were sterilized by passage through a $0.4 \mu \mathrm{m}$ Millipore filter before use. The natural water was collected from Muko River ( $\mathrm{pH}$ 7.4) and Nishinomiya Seaside ( $\mathrm{pH}$ 7.8) in Hyogo Prefecture. The buffer solutions were prepared by dissolving the component salts in deionizeddistilled water at the concentrations reported previously. ${ }^{7)}$ One liter of the aqueous solution containing ${ }^{14} \mathrm{C}-\mathrm{I}$ at $1 \mathrm{ppm}$ or $10 \mathrm{ppm}$ was placed in a 1-liter quartz flask, and exposed to sunlight for 32 days ( $8 \mathrm{hr}$ per day from September to October in 1981) at Takarazuka, Hyogo, Japan. During the experiment, carbon dioxide-free air was continuously supplied over the water surface at $100 \mathrm{ml} / \mathrm{hr}$, and any volatile compounds were collected in polyurethane foam plug and $0.5 \mathrm{~N} \mathrm{NaOH}$ solution $(400 \mathrm{ml})$ linked in series. A dark control experiment was also carried out by covering the flask with aluminum foil.

At specified intervals, the polyurethane foam plug was eluted with acetone $(30 \mathrm{ml} \times 3)$, and the extract was radioassayed. The $\mathrm{NaOH}$ solution was radioassayed using Aquasol ${ }^{\circledR}-2$ (New England Nuclear). An aliquot of the water sample $(50 \mathrm{ml})$ was extracted with ethyl acetate $(50 \mathrm{ml} \times 3)$ at $\mathrm{pH} 7$, and the remaining aqueous layer was extracted with ethyl acetate $(50 \mathrm{ml} \times 3)$ at $\mathrm{pH} 2$. The aqueous and organic layers were radioassayed, and the combined ethyl acetate extracts were concentrated and examined by TLC in solvent systems $(A \times B)$.

\section{Photolysis of Fenitrothion on Soil Surface}

Two kinds of soils were used in the experiment. Utsunomiya silty loam soil with clay and organic matter contents of $40 \%$ and $19 \%$ respectively, and cation exchange capacity 
(CEC) of $56 \mathrm{meq} / 100 \mathrm{~g}$ dry soil. Moriyama silty loam soil with clay and organic matter contents of $42 \%$ and $2.5 \%$ respectively, and $\mathrm{CEC}$ of $18 \mathrm{meq} / 100 \mathrm{~g}$ dry soil. The soil thin layer plates $(10 \times 10 \mathrm{~cm}, 50 \mu \mathrm{m}$ thickness) were prepared with fine particles of soil passed through a 2-mm sieve, according to the methods of Helling and Turner. ${ }^{8)}$

Onto each soil TLC plate, one ml solution of ${ }^{14} \mathrm{C}-\mathbf{I}$ in chloroform was applied with a brush at $10 \mu \mathrm{g} / \mathrm{cm}^{2}$, and then exposed to sunlight for 12 days ( $8 \mathrm{hr}$ per day during June in 1979) at Takarazuka, Hyogo, Japan. During the experiment, the water contents of Utsunomiya and Moriyama soil TLC plates decreased from $12 \%$ to $0.6 \%$ and from $5 \%$ to $0.7 \%$, respectively. At intervals, the soil TLC plates were scraped and extracted twice with $90 \mathrm{ml}$ of methanol-water $(3 / 1)$. The combined extracts were concentrated and examined by TLC in solvent systems $(\mathrm{A} \times \mathrm{B})$.

\section{Determination of Quantum Yield of Fenitro- thion}

The quantum yield of $\mathbf{I}$ was determined by comparing the photolysis rate with that of parathion at $313 \mathrm{~nm}$ or methyl parathion at $366 \mathrm{~nm}$ as a reference compound, using a merry-go-round type photochemical apparatus as reported previously. ${ }^{6}{ }^{14} \mathrm{C}$-Parathion was dissolved in distilled water at $0.2 \mathrm{ppm}$, and ${ }^{14} \mathrm{C}$-methyl parathion was dissolved in acetate buffer (pH 5) at $1.0 \mathrm{ppm}$. Each of the aqueous solution $(7 \mathrm{ml})$ was placed in a quartz tube and irradiated for up to $30 \mathrm{hr}$.

\section{Hydrolysis of Fenitrothion in Water}

Buffer solutions ( $\mathrm{pH}$ 2.0, 5.1, 6.3, 7.1, 8.1, $9.0,10.1,10.8,11.5)$ at almost the same ionic strength $(\mu 0.2-0.3)$ were prepared as reported previously. ${ }^{7)}$ The $\mathrm{pH}$ of the solutions was adjusted to the desired values at 15,30 and $45^{\circ} \mathrm{C}$, and checked with a $\mathrm{pH}$ meter model F-7AD (Horiba Co., Ltd.) calibrated with the standard buffer solutions. ${ }^{14} \mathrm{C}-\mathrm{I}$ was dissolved in the filter-sterilized buffer solutions or natural river and sea water, and stirred at $25^{\circ} \mathrm{C}$ for 5 min to attain a level of $1 \mathrm{ppm}$. Each $40 \mathrm{ml}$ solution in a $50 \mathrm{ml}$ volumetric flask was immersed in a darkened, thermostated-water bath at 15,30 and $45^{\circ} \mathrm{C}$. At various intervals,
$2 \mathrm{ml}$ aliquot of the solution was extracted with ethyl acetate $(5 \mathrm{ml} \times 3)$ at $\mathrm{pH} 1$. The combined ethyl acetate extracts were washed with sat. $\mathrm{NaCl}$ solution, concentrated and examined by TLC in solvent systems $(B \times C)$.

\section{RESULTS}

\section{Direct Photolysis Rate of Fenitrothion in Water}

The half-lives of $\mathbf{I}$ by direct photolysis in distilled water or buffer solutions at $\mathrm{pH} \mathrm{3,7}$ and 9 near the water surface was calculated by the quantum yield $(\Phi)$ and the rate of specific sunlight absorption $\left(k_{\mathrm{a}}\right)$, according to the method reported previously. ${ }^{6)}$ Four replicate measurements determined the quantum yield of $\mathbf{I}$ to be $8.0 \times 10^{-4}$ (at $313 \mathrm{~nm}$ in distilled water) and $7.8 \times 10^{-4}$ (at $366 \mathrm{~nm}$ in distilled water), and $4.0 \times 10^{-4}, 5.9 \times 10^{-4}$ and $6.3 \times 10^{-4}$ (at $313 \mathrm{~nm}$ in $\mathrm{pH} 3,7$ and 9 buffer solutions, respectively) within all experimental errors. Meanwhile, the $k_{\mathrm{a}}$ values were obtained by summing up the molecular extinction coefficient multiplied by the fraction of solar energy during the range, in which the UV spectra of I and the UV spectra of sunlight were overlapping $(\lambda 297.5-380 \mathrm{~nm})$. Almost the same $k_{\mathrm{a}}$ values were obtained in each water, because the UV spectra of $\mathbf{I}$ at $10 \mathrm{ppm}$ were not altered to any great degree with the variation of $\mathrm{pH}$ or by the components in buffer solutions.

According to the equation of $T_{1 / 2}=0.693 /$ $\Phi k_{\mathrm{a}}$, the photolysis half-life in fall at 40 degree north latitude was calculated to be 1.4 days, 2.1 days, 1.1 days, and 1.2 days in distilled water and buffer solutions at $\mathrm{pH} \mathrm{3,7}$ and 9 , respectively.

\section{Photolysis of Fenitrothion in Water}

On exposure to sunlight, I was rapidly photodecomposed in each water with half-lives of less than 1.5 days (Table 1). It appears that there is no significant difference in the photolysis rate between $1 \mathrm{ppm}$ and $10 \mathrm{ppm}$, and between buffer solutions at $\mathrm{pH} 3,7$ and 9 . I in water decreased to less than $5 \%$ of the applied ${ }^{14} \mathrm{C}$ after 5 days, and to less than $2 \%$ after 32 days. In contrast, degradation of $\mathbf{I}$ in the dark was slow with half-lives of more than 34 days in distilled water, buffer solutions, and natural river and sea water. The exception was 
Table 1 Half-life values for fenitrothion under sunlight or dark conditions.

\begin{tabular}{|c|c|c|c|c|}
\hline & \multirow{2}{*}{$\begin{array}{c}\text { Substrate } \\
\text { conc. (ppm) }\end{array}$} & \multirow{2}{*}{$\mathrm{pH}$} & \multicolumn{2}{|c|}{ Half-life (days) } \\
\hline & & & Sunlight & Dark \\
\hline \multicolumn{5}{|l|}{ Water } \\
\hline \multirow[t]{2}{*}{ Distilled water } & 1 & 5.9 & 0.6 & $>32$ \\
\hline & 10 & 5.9 & $1.0[1.4]^{\mathrm{a})}$ & $>32$ \\
\hline \multirow[t]{3}{*}{ Buffer solution } & 10 & 3.0 & $1.5[2.1]^{a)}$ & $>32$ \\
\hline & & 7.0 & $1.0[1.1]^{\mathrm{a})}$ & $>32$ \\
\hline & & 9.0 & $0.9[1.2]^{\mathrm{a})}$ & 24 \\
\hline River water & 10 & 7.4 & 1.1 & $>32$ \\
\hline Sea water & 10 & 7.8 & 0.9 & $>32$ \\
\hline \multicolumn{5}{|l|}{ Soil } \\
\hline Utsunomiya soil & $10^{b)}$ & 5.2 & 1.0 & $>12$ \\
\hline Moriyama soil & $10^{\mathrm{b})}$ & 6.4 & 1.0 & $>12$ \\
\hline
\end{tabular}

a) Values in parenthesis indicate the calculated half-life of fenitrothion, b) $\mu \mathrm{g} / \mathrm{cm}^{2}$.

the buffer solution at $\mathrm{pH} 9$, in which $\mathbf{I}$ was degraded with the half-life of about 24 days.

At least 50 photoproducts were detected in each aqueous solution as determined by TLC in solvent systems $(\mathrm{A} \times \mathrm{B})$, and 18 products were identified by TLC cochromatography with the authentic standards. The concentrations are listed in Table 2. Although all of the identified products were detected in each water tested, the proportion varied depending upon the $\mathrm{pH}$ values. A main photoproduct was XII in $\mathrm{pH} 3$ buffer solution and distilled water as reported previously, ${ }^{1)}$ which amounted to 4.1$11.5 \%$ of the applied ${ }^{14} \mathrm{C}$ after 2 days. In contrast, both XII and XVI were predominant in buffer solutions at $\mathrm{pH} 7$ and $\mathrm{pH} \mathrm{9,} \mathrm{and} \mathrm{river}$ $(\mathrm{pH} 7.4)$ and sea $(\mathrm{pH} 7.8)$ water. The latter product was of more importance in the neutral and slightly basic water, which amounted to $5.2-19.0 \%$ of the applied ${ }^{14} \mathrm{C}$ after 2 days. However, XII and XVI were degraded further by sunlight. The other identified photoproducts were less than $3 \%$ of the applied ${ }^{14} \mathrm{C}$. Approximately $4-39 \%$ of the applied ${ }^{14} \mathrm{C}$ remained to be identified, but each of the products did not exceed $2 \%$ of the applied ${ }^{14} \mathrm{C}$ in any water tested.

On prolonged exposure to sunlight, there was an increase in the amounts of the volatile and unextracted radiocarbon. After 32 days, the volatile ${ }^{14} \mathrm{C}$ amounted to $21.5-45.0 \%$ of the applied ${ }^{14} \mathrm{C}$. Most of the radioactivity was trapped in the $\mathrm{NaOH}$ solution, and was con- sidered to be ${ }^{14} \mathrm{CO}_{2}$ because more than $99 \%$ was precipitated as $\mathrm{Ba}^{14} \mathrm{CO}_{3}$ by addition of $1 \mathrm{~N} \mathrm{BaCl}$ aqueous solution. The unextracted ${ }^{14} \mathrm{C}$ amounted to $29.3-51.4 \%$ of the applied ${ }^{14} \mathrm{C}$ during the same period.

\section{Photolysis of Fenitrothion on Soil Surface}

On exposure to sunlight, I disappeared from two kinds of soil TLC plates through photodegradation and volatilization, with the halflife of about 1 day. Two major photoproducts were detected in extracts of the soils, and identified as II and III by TLC cochromatography with authentic standards in solvent systems $(\mathrm{B} \times \mathrm{C})$. II amounted to $3.6-9.4 \%$ of the applied ${ }^{14} \mathrm{C}$ after 1 day, but decreased thereafter (Table 3). In contrast, III amounted to $20.4-23.1 \%$ of the applied ${ }^{14} \mathrm{C}$ after 12 days. The unidentified products remained at the origin of TLC plate in solvent systems $(B \times C)$. The unextracted ${ }^{14} \mathrm{C}$ was less than $5 \%$ of the applied ${ }^{14} \mathrm{C}$.

\section{Hydrolysis of Fenitrothion in Water}

The psuedo-first-order rate constants $\left(k_{\mathrm{H}}\right)$ for the hydrolysis of $\mathbf{I}$ in buffer solutions were determined (Table 4). The preliminary experiments verified that the hydrolysis proceeded through first order in terms of $\mathbf{I}$ concentrations, because a satisfactory agreement was obtained among the $k_{\mathrm{H}}$ values for hydrolysis at $\mathrm{pH} 8$ at three different concentrations $(0.2,0.6$ and 1.0 $\mathrm{ppm})$. The $\mathrm{pH}$ dependence for hydrolysis of 


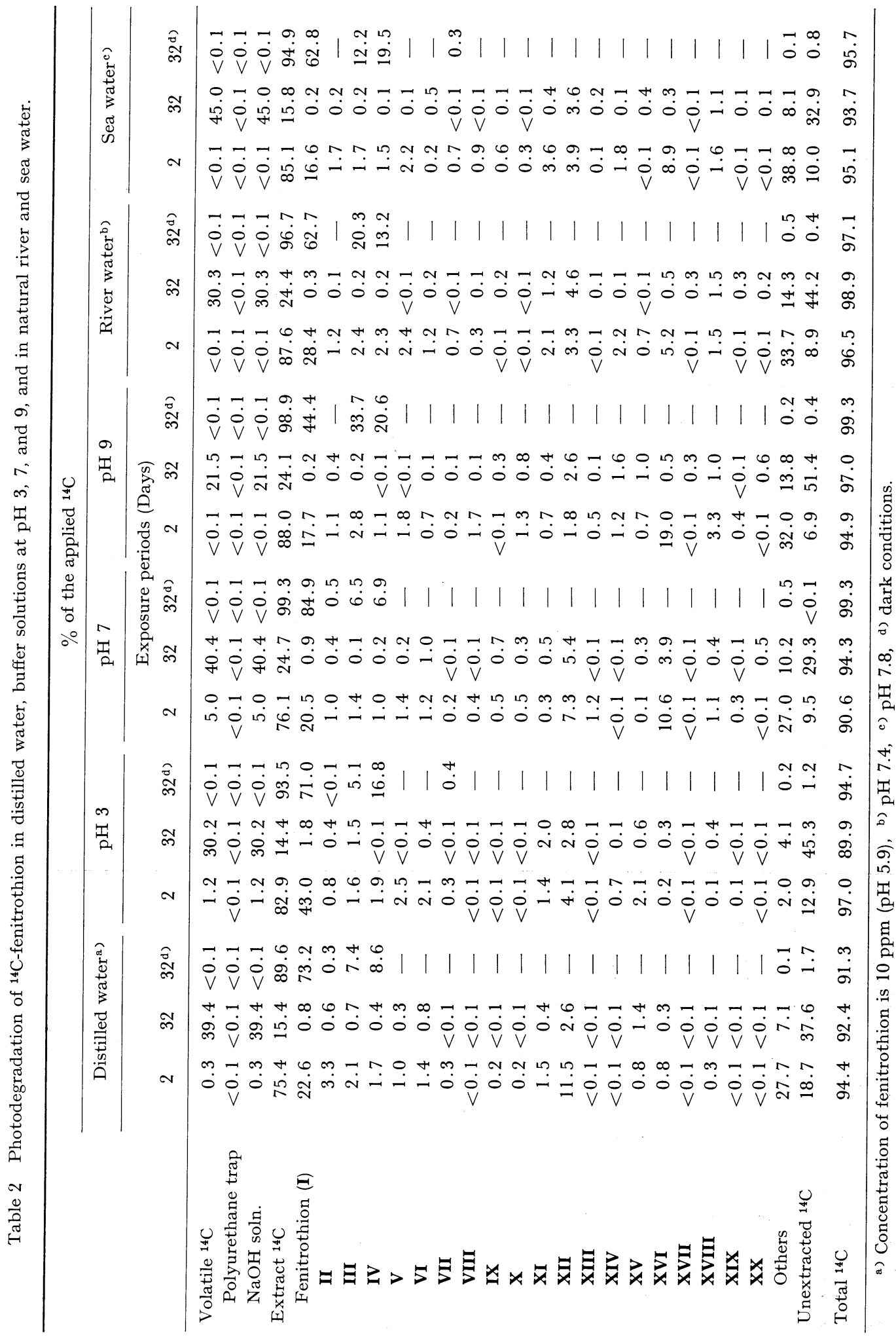


Table 3 Photodegradation of ${ }^{14} \mathrm{C}$-fenitrothion on soils.

\begin{tabular}{|c|c|c|c|c|c|c|c|c|c|c|}
\hline & \multicolumn{10}{|c|}{$\%$ of the applied ${ }^{14} \mathrm{C}$} \\
\hline & \multicolumn{5}{|c|}{ Utsunomiya soil } & \multicolumn{5}{|c|}{ Moriyama soil } \\
\hline & \multicolumn{4}{|c|}{ Sunlight } & Dark & \multicolumn{4}{|c|}{ Sunlight } & \multirow[t]{2}{*}{ Dark } \\
\hline & \multicolumn{9}{|c|}{ Exposure periods (days) } & \\
\hline & 1 & 3 & 6 & 12 & 12 & 1 & 3 & 6 & 12 & 12 \\
\hline Extracted ${ }^{14} \mathrm{C}$ & 81.4 & 55.2 & 35.7 & 30.3 & 97.9 & 82.5 & 66.8 & 46.1 & 34.1 & 98.0 \\
\hline I & 55.4 & 28.9 & 3.3 & 1.1 & 96.0 & 52.3 & 33.6 & 11.3 & 3.0 & 95.5 \\
\hline II & 3.6 & 2.1 & 1.3 & 0.7 & $<0.1$ & 9.4 & 7.3 & 4.7 & 2.9 & - \\
\hline III & 15.9 & 18.7 & 24.3 & 23.1 & 1.3 & 13.8 & 20.1 & 21.7 & 20.4 & 1.8 \\
\hline others & 6.5 & 5.5 & 6.8 & 5.4 & 0.6 & 7.0 & 5.8 & 8.4 & 7.8 & 0.7 \\
\hline Bound ${ }^{14} \mathrm{C}$ & 2.8 & 2.0 & 4.4 & 4.2 & 0.1 & 2.6 & 1.9 & 4.5 & 4.3 & 1.6 \\
\hline Total & 84.2 & 57.2 & 40.1 & 34.5 & 98.0 & 85.1 & 68.7 & 50.6 & 38.4 & 99.6 \\
\hline
\end{tabular}

Table 4 The pseudo-first-order rate constants $\left(\sec ^{-1}\right)$ for hydrolysis of fenitrothion $\left(k_{\mathrm{H}}\right)$ and for formation of III $(k \mathbf{I I I})$ and IV $\left(k_{\mathbf{I V}}\right)$ at 15,30 and $45^{\circ} \mathrm{C}$.

\begin{tabular}{|c|c|c|c|c|c|c|c|c|c|}
\hline \multirow{2}{*}{$\mathrm{pH}$} & \multicolumn{3}{|c|}{$15^{\circ} \mathrm{C}$} & \multicolumn{3}{|c|}{$30^{\circ} \mathrm{C}$} & \multicolumn{3}{|c|}{$45^{\circ} \mathrm{C}$} \\
\hline & $k_{\mathrm{H}} \times 10^{8}$ & $k_{\mathbf{I I I}} \times 10^{8}$ & $k_{\mathbf{I V}} \times 10^{8}$ & $k_{\mathrm{H}} \times 10^{7}$ & $k_{\mathbf{I I I}} \times 10^{7}$ & $k_{\mathbf{I V}} \times 10^{7}$ & $k_{\mathrm{H}} \times 10^{7}$ & $k_{\mathbf{I I I}} \times 10^{7}$ & $k_{\mathbf{I V}} \times 10^{7}$ \\
\hline 2.0 & 1.3 & 0.64 & 0.64 & 1.2 & 0.24 & 0.70 & 9.3 & 2.3 & 6.6 \\
\hline 5.0 & 1.3 & 0.43 & 0.80 & 1.3 & 0.23 & 0.91 & 11 & 2.3 & 7.2 \\
\hline 6.3 & 1.6 & 0.80 & 0.89 & 1.4 & 0.48 & 0.91 & 10 & 2.5 & 7.1 \\
\hline 7.1 & 1.5 & 0.56 & 0.80 & 1.4 & 0.50 & 0.82 & 11 & 2.2 & 8.3 \\
\hline 8.1 & 1.7 & 0.54 & 1.0 & 1.9 & 0.80 & 0.94 & 12 & 3.4 & 8.4 \\
\hline 9.0 & 3.9 & 2.2 & 1.5 & 4.5 & 2.0 & 2.2 & 21 & 8.1 & 11 \\
\hline 10.1 & 17 & 12 & 4.4 & 17 & 9.7 & 5.7 & 98 & 57 & 26 \\
\hline 10.8 & 98 & 76 & 13 & 72 & 49 & 20 & 450 & 340 & 100 \\
\hline 11.5 & 800 & 780 & 18 & 330 & 320 & 8.0 & - & - & 一 \\
\hline $\begin{array}{l}\text { River } \\
\text { (pH 7.1) }\end{array}$ & 1.6 & 0.60 & 0.87 & 1.3 & 0.44 & 0.93 & 11 & 3.0 & 7.3 \\
\hline $\begin{array}{l}\text { Sea } \\
\text { (pH 7.8) }\end{array}$ & 1.8 & 0.50 & 1.4 & 2.1 & 0.47 & 1.5 & 12 & 1.7 & 10 \\
\hline
\end{tabular}

I at 15,30 and $45^{\circ} \mathrm{C}$ is expressed in Fig. 1 by a plot $\log k_{\mathrm{H}}$ as a function of $\mathrm{pH}$. From this expression, it can be seen that the hydrolysis proceeds through a neutral reaction between $\mathrm{pH} 2$ and $\mathrm{pH} \mathrm{7,} \mathrm{because} \mathrm{the} \mathrm{hydrolysis} \mathrm{rate} \mathrm{is}$ almost independent upon $\mathrm{pH}$ at any temperature tested. In contrast, the base-catalyzed process is predominant above $\mathrm{pH} 10$ where a slope of +1 is observed, and both basic and neutral reactions occur between $\mathrm{pH} 7$ and $\mathrm{pH}$ 10. The acid-catalyzed hydrolysis is not significant, as compared with the neutral and basecatalyzed hydrolysis, and therefore the pseudofirst-order rate constant $\left(k_{\mathrm{H}}\right)$ and the half-life $\left(T_{1 / 2}\right)$ can be expressed by Eqs. (1) and (2), respectively,

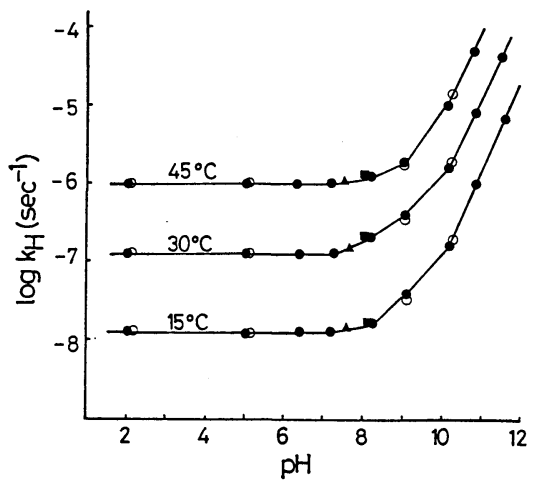

Fig. 1 The pH-rate profile for fenitrothion hydrolysis.

๑: observed, $\bigcirc$ : calculated, $\mathbf{\Delta}$ : river water,

a: sea water. 
Table 5 Temperature dependence of rate constants in neutral $\left(k_{\mathrm{N}}\right)$ and base-catalyzed $\left(k_{\mathrm{B}}\right)$ hydrolysis of fenitrothion.

\begin{tabular}{|c|c|c|c|c|c|}
\hline & \multirow{2}{*}{$\underset{\left.{ }^{\circ} \mathrm{C}\right)}{\text { Temp. }}$} & \multicolumn{3}{|c|}{ Rate constants } & \multirow[b]{2}{*}{ Arrhenius expression } \\
\hline & & $\begin{array}{c}k_{\mathrm{H}} \times 10^{7} \\
\left(\mathrm{sec}^{-1}\right)\end{array}$ & $\begin{array}{c}k_{\mathrm{N}} \times 10^{7} \\
\left(\mathrm{sec}^{-1}\right)\end{array}$ & $\begin{array}{c}k_{\mathrm{B}} \\
\left(\mathrm{M}^{-1} \cdot \mathrm{sec}^{-1}\right)\end{array}$ & \\
\hline \multirow{3}{*}{$\begin{array}{l}\text { Neutral } \\
(\mathrm{pH} \mathrm{5.0)}\end{array}$} & 15 & 0.13 & 0.13 & & \multirow{3}{*}{$\log k_{\mathrm{N}}=12.4-5.84 \times 10^{3} / T$} \\
\hline & 30 & 1.3 & 1.3 & & \\
\hline & 45 & 11 & 11 & & \\
\hline \multirow{3}{*}{$\begin{array}{c}\text { Base-catalyzed } \\
(\mathrm{pH} \mathrm{10.8)}\end{array}$} & 15 & 9.8 & 0.13 & $1.5 \times 10^{-3}$ & \multirow{3}{*}{$\log k_{\mathrm{B}}=14.4-4.97 \times 10^{3} / T$} \\
\hline & 30 & 72 & 1.3 & $1.1 \times 10^{-2}$ & \\
\hline & 45 & 450 & 11 & $7.0 \times 10^{-2}$ & \\
\hline
\end{tabular}

$$
\begin{gathered}
k_{\mathrm{H}}=k_{\mathrm{N}}+k_{\mathrm{B}}\left[\mathrm{OH}^{-}\right] \\
T_{1 / 2}=\ln 2 / k_{\mathrm{H}}
\end{gathered}
$$

where $k_{\mathrm{N}}$ and $k_{\mathrm{B}}$ are the rate constants for the neutral and basic hydrolysis, respectively.

Temperature dependence of $k_{\mathrm{N}}$ and $k_{\mathrm{B}}$ was determined at $\mathrm{pH} 5.0$ and $\mathrm{pH} 10.8$ respectively, where the neutral and base-catalyzed processes were predominant, using the Arrhenius equation. Table 5 shows the Arrhenius expression for $k_{\mathrm{H}}$ and $k_{\mathrm{B}}$, along with the rate constants $k_{\mathrm{H}}, k_{\mathrm{N}}$ and $k_{\mathrm{B}}$ at $\mathrm{pH} 5$ and $\mathrm{pH} 10.8$. As shown in Fig. 1, the $\log k_{\mathrm{H}}$ calculated from Eq. (1) and the Arrhenius expression was in good accord with the observed values in buffer solutions. I yielded two major hydrolysis products, which were identified as III and IV by TLC cochromatography with the authentic standards in solvent systems $(\mathrm{B} \times \mathrm{C})$. The rate constants $k_{\text {III }}$ and $k_{\mathbf{I V}}$ for the respective formation of III and IV were determined, and the results are listed in Table 4. III was predominant above $\mathrm{pH} \mathrm{10,} \mathrm{whereas} \mathrm{IV} \mathrm{was} \mathrm{predominant} \mathrm{in} \mathrm{the}$ acidic and neutral water, particularly at $45^{\circ} \mathrm{C}$. In contrast, almost the same amounts of III and IV were formed at $\mathrm{pH}$ 8-9.

To determine if this laboratory data could be extrapolated to natural water, the rate constants for hydrolysis of $\mathbf{I}$ and for formation of the hydrolysis products in river and sea water were also determined (Table 4). The kinetic data in natural water were in good agreement with those in buffer solutions at the same $\mathrm{pH}$. Therefore, the rate constant for hydrolysis of $\mathbf{I}$ in natural water was found to be also expressed by Eq. (1) and the Arrhenius expression for $k_{\mathrm{N}}$ and $k_{\mathrm{B}}$. The half-life of disappearance of $\mathbf{I}$ by hydrolysis within the ranges of $\mathrm{pH} 5-9$, normally found in natural water, ${ }^{9)}$ could be estimated to be 200-630 days at $15^{\circ} \mathrm{C}, 17-61$ days at $30^{\circ} \mathrm{C}$, and $4-8$ days at $45^{\circ} \mathrm{C}$.

\section{DISCUSSION}

Fenitrothion (I) has absorption maxima significantly below $290 \mathrm{~nm}$ but has measurable absorption tail above the baseline in its absorption spectrum at wavelength greater than 290 $\mathrm{nm}$. The UV spectrum in distilled water exhibits a 204-nm $(\epsilon$ 18,800) for the allowed $\pi-\pi^{*}$ transition of the phenyl ring and a 268$\mathrm{nm}$ band $(\epsilon 5550)$, which is essentially $\mathrm{n}-\pi^{*}$ in character, resulting from the lower energy band of the aromatic ring. These $\pi-\pi^{*}$ and $n-\pi^{*}$ transitions can lead to the production of either singlet or triplet excited state so no unique excited state can be invoked to explain the variety of photochemical reactions.

The photolysis half-lives of $\mathbf{I}$ in water and on soil surface are summarized in Table 1 . The half-life values of $\mathbf{I}$ in water, calculated by the quantum yield and specific rates of sunlight absorption, were close to the observed values. As estimated from the results, it appears that the photolysis rate in water is not significantly affected by the $\mathrm{pH}$ or substrate concentrations ( $1 \mathrm{ppm}$ and $10 \mathrm{ppm})$. In fact, the quantum yield or UV absorption spectrum of $\mathbf{I}$ was not altered to a great extent within the ranges of pH 3-9. Similarly, the photolysis half-life of $\mathbf{I}$ in distilled water was calculated as functions of season and latitude, and the results are shown in Fig. 2. As with other pesticides, ${ }^{9-11)}$ the latitudinal variation of photolysis rate of $\mathbf{I}$ is 


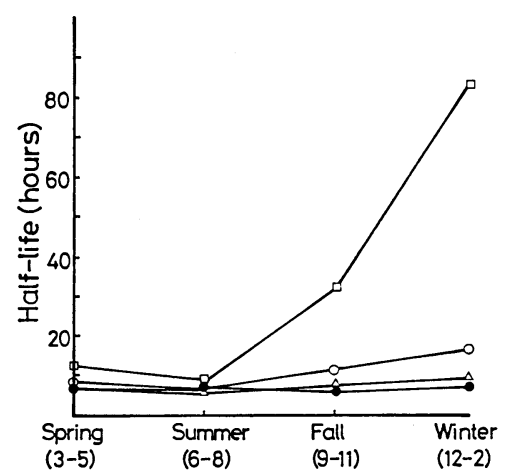

Fig. 2 Dependence of half-life of fenitrothion upon season and northern latitude.

๑: $0^{\circ} \mathrm{N}, \triangle: 20^{\circ} \mathrm{N}, \bigcirc: 40^{\circ} \mathrm{N}, \square: 60^{\circ} \mathrm{N}$.

relatively small in summer, but prominent in fall and winter, particularly at higher latitude, due to a significant decrease of sunlight intensity in the UV region.

Based upon the identified products, the proposed photodegradation pathways for $\mathbf{I}$ in water and on soil are shown in Fig. 3. I was photodecomposed in water via oxidation of $\mathrm{P}=\mathrm{S}$ to $\mathrm{P}=\mathrm{O}$, oxidation of the aryl methyl group to the carboxyl group, reduction of the nitro group to the amino group, coupling of the carboxyl group with the amino group, cleavage of the $\mathrm{P}$-O -aryl or $\mathrm{P}$-O-methyl linkage, isomeri- zation, formation of the benzoisoxazole derivative with subsequent formation of the sevenmembered ring (azepine derivative) through Beckmann rearrangement, and photomineralization of the aromatic ring to carbon dioxide. It is likely that oxidation at the aryl methyl group proceeds by the ortho-effect of the nitro group, because the photo-iduced oxidation at the aryl methyl group was not observed with Cremart ${ }^{\circledR}$, which possessed the nitro group at the para-position relative to the aryl methyl group. ${ }^{12)}$ Although the mechanism for formation of XII and XIII was not clarified, the photoproducts might be formed through an excited comples with a six-membered ring.

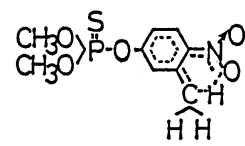

In fact, tolclofos-methyl possessing no nitro group in the phenyl moiety was not subjected to the photo-induced oxidation of the aryl methyl group. ${ }^{13)}$ Meanwhile, the benzoisoxazole derivative might be formed through the intermediate with the aci-nitro form..$^{14,15)}$

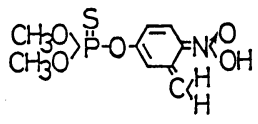

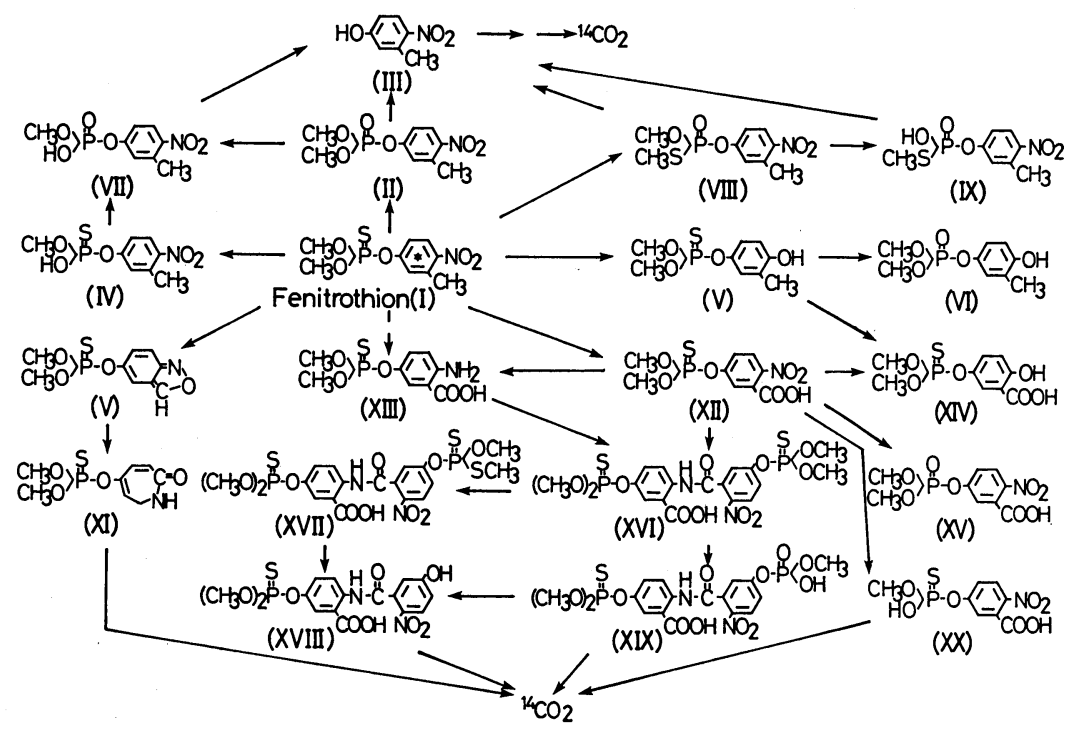

Fig. 3 The proposed photodegradation pathways for fenitrothion in water and on soil. 
Although the rate of photolysis was not significantly altered with variation of $\mathrm{pH}$, the formation of the major photoproducts were $\mathrm{pH}$ dependent. The oxidation at the aryl methyl group leading to the formation of XII was predominant in the neutral and acidic water, whereas the dimeric product XVI was more predominantly formed in the slightly basic water. However, both compounds were photodegraded further via oxidation of $\mathrm{P}=\mathrm{S}$ to $\mathrm{P}=\mathrm{O}$, cleavage of the $\mathrm{P}-\mathrm{O}$-aryl or $\mathrm{P}-\mathrm{O}$-methyl linkage and/or isomerization. Thus, photoproducts of $\mathbf{I}$ in water decreased on prolonged exposure to sunlight, and the terminal products were ${ }^{14} \mathrm{CO}_{2}$ and the unextracted ${ }^{14} \mathrm{C}$ residues. The unextracted residues might be polymerized compounds such as humic acid or highly polar products like formic acid, as reported previously. ${ }^{1)}$ In contrast, the major photodegradation pathways of $\mathbf{I}$ on soils were oxidation from $\mathrm{P}=\mathrm{S}$ to $\mathrm{P}=\mathrm{O}$ and cleavage of the $P$ - $O$-aryl linkage, and different from those in water.

The rates and routes of degradation of $\mathbf{I}$ by photolysis and hydrolysis in natural river and sea water were similar to those in buffer solutions at the same $\mathrm{pH}$. The hydrolysis at $\mathrm{pH}$ 5-9, normally found in natural water, was slow and appeared to be of minor importance, compared with the photolysis. Recently, Nambu et al. ${ }^{16)}$ reported that fenitrothion was rapidly mineralized to carbon dioxide by microorganisms in natural river and pond water. It is likely, therefore, that photolysis and microbial processes are the main degradation routes of fenitrothion in the natural aquatic environment.

\section{REFERENCES}

1) H. Ohkawa, N. Mikami \& J. Miyamoto: Agric. Biol. Chem. 38, 2247 (1974)

2) R. Greenhalgh \& W. D. Marshall: J. Agric. Food Chem. 24, 708 (1976)

3) Y. Takimoto, M. Ohshima \& J. Miyamoto: Abstr. Papers 5th Annu. Meet. Pestic. Sci. Soc. Jpn., No. 143, 1980

4) R. Greenhalgh, K. L. Dhawan \& P. Weinberger: J. Agric. Food Chem. 28, 102 (1980)

5) A. Yoshitake, K. Kawahara, T. Kamada \& M. Endo: J. Labelled Compd. Radiopharm. 13, 323 (1976)

6) N. Mikami, N. Takahashi, K. Hayashi \& J. Miyamoto: J. Pesticide Sci. 5, 225 (1980)
7) N. Mikami, K. Imanishi, H. Yamada \& J. Miyamoto: J. Pesticide Sci. 9, 223 (1984)

8) C. S. Helling \& B. C. Turner: Science 162, 562 (1978)

9) R. G. Zepp, N. L. Wolfe, J. A. Gordon \& G. L. Baughman: Environ. Sci. Technol. 9, 1145 (1975)

10) R. G. Zepp, N. L. Wolfe \& J. A. Gordon: Chemosphere 12, 93 (1973)

11) R. G. Zepp, N. L. Wolfe, L. V. Azarrage, R. H. Cox \& C. W. Pape: Arch. Environ. Contam. Toxicol. 6, 305 (1977)

12) N. Mikami, H. Ohkawa \& J. Miyamoto: J. Pesticide Sci. 2, 119 (1977)

13) N. Mikami, K. Imanishi, H. Yamada \& J. Miyamoto: J. Pesticide Sci. 9, 215 (1984)

14) H. S. Mosher, C. Souers \& R. Hardwick: J. Chem. Phys. 32, 1888 (1960)

15) R. Hardwick \& H. S. Mosher: J. Chem. Phys. 36, 1402 (1962)

16) K. Nambu, K. Ito, H. Yamada \& J. Miyamoto: unpublished observation

\section{要約}

\section{フェニトロチオンの水中および土壤表面での光} 分解と水中での加水分解

三上信可，今西久美子，山田宏彦，宮本純之

太陽光照射条件下でのフ ニトロチオンの光分解半減

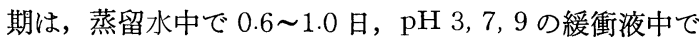
はそれぞれ 1.5，1.0，0.9日であり，また河川水および海 水中では 0.9 1.0日であった. フェニトロチオンの蒸留 水中に特ける量子収率は $8.0 \times 10^{-4}$ であり，この值を使 って計算から求めた北緯 $40^{\circ}$ の秋季に拈ける半減期は 1.4 日と実測值とほぼ一致した。一方, 土壤薄層プレート上 に処理したフェニトロチオンは，扣もに揮散や光分解に より半減期が約 1 日の速度で分解・消失した．水中では 抢子に, $\mathrm{P}=\mathrm{S}$ の $\mathrm{P}=\mathrm{O}$ への酸化, ベンゼン環メチルのカ ルボン酸への酸化,ニトロ基のアミノ基への還元,カルボ ン酸とアミノ体が縮合したアミド化合物の生成, $P-O-$ アリル和よび $P-O-$ メル結合の開裂, 異性化, ベンゾ イソキサゾール誘導体の生成, さらにベックマン転位に よる 7 員環 (アゼピン誘導体) の生成を経て分解された。 水中での主光分解物は $\mathrm{pH}$ により異なり, 弱酸性特よび 中性ではベンゼン環メチル基がカルボン酸に酸化された 分解物 (カルボキシスミチオン) が主であるのに対して, 弱塩基性ではカルボキシスミチオンとそのアミノ体が縮 合したアミド化合物が主分解物であった。これらの光分 解物はさらに ${ }^{14} \mathrm{CO}_{2}$ やフミン酸様物質に分解された。一 
方, 土壤表面では $\mathrm{P}=\mathrm{S}$ の $\mathrm{P}=\mathrm{O}$ への酸化，P-O-アリル 結合の開裂がフェニトロチオンの主光分解反応であっ た. 通常自然水中に打いて見いだされる $\mathrm{pH}$ 5 9 の範 囲でのフェニトロチオンの加水分解半減期は $15^{\circ} \mathrm{C}$ で $200 \sim 630$ 日， $30^{\circ} \mathrm{C}$ で $17 \sim 61$ 日， $45^{\circ} \mathrm{C}$ で 4 8 日であっ
た. $\mathrm{pH} 10$ 以上の塩基性条件下では $P-O-ア リ ル$ 結合 の開裂物が主分解物であるのに対して, $\mathrm{pH} 8$ 以下では $P-O-メ チ ル$ 結合の開裂物が主分解物であった，河川水 扣よび海水中のフェニトロチオンの光分解および加水分 解様式は同じ $\mathrm{pH}$ を示す緩衝液中とほぼ同じであった。 